\title{
Effectiveness of Video-Assisted Teaching Program on Knowledge and Attitude Regarding Temporary Family Planning Method among Postnatal Mothers
}

\author{
Monisha U. ${ }^{1}$, Indu Balakrishnan² \\ ${ }^{1}$ Lecturer, Amrita College of Nursing, Amrita Institute of Medical Science and Research Centre, AMRITA \\ Viswavidhyapeetham, Health Science Campus, Kochi, Kerala, ${ }^{2}$ Assistant Professor, Govt. College of Nursing, \\ Ernakulam, HMT Colony, Kalamassery, Kochi, Kerala, India
}

\begin{abstract}
The present study was intended to evaluate the effectiveness of video-assisted teaching program on knowledge and attitude regarding temporary family planning method among postnatal mothers. Objectives were to assess the knowledge and attitude regarding temporary family planning method among postnatal mothers,evaluate the effectiveness of video-assisted teaching program on knowledge and attitude and to find out its association with socio personal variables. The theoretical framework adopted for the study was Betty Neuman Systems Model. The investigator adopted quantitative pre experimental approach and the research design used was one group pre test post test design. The study was conducted in the postnatal ward and family planning OPD of Govt. T.D. Medical College Hospital, Alappuzha. Fifty sample were selected by purposive sampling. The socio personal variables were gathered by self reporting. The knowledge and attitude were assessed by Structured Questionnaire and Modified Likert scale respectively. The sample were provided witha video-assisted teaching program on second postnatal day in the postnatal ward and the post test were conducted on 45 days after normal vaginal delivery in the family planning OPD. The findings revealed that there was a significant difference in the level of knowledge and attitude among postnatal mothers after videoassisted teaching program at $\mathrm{p}<0.001$. Thus it was concluded that video-assisted teaching program had a significant effect in improving the level of knowledge and attitude regarding temporary family planning method among postnatal mothers.
\end{abstract}

Keywords: Video-assisted teaching program; Knowledge; Attitude; Socio personal variables.

\section{Introduction}

India will surpass China to become the most populous nation in the world by 2022. Currently, the population of China is approximately 1.38 billion compared with

\section{Corresponding Author:}

Ms. Monisha U.

Lecturer, Department of Obstetrics and Gynecological Nursing, Amrita College of Nursing, Amrita Institute of Medical Science and Research Centre, AMRITA Viswavidhyapeetham, Health Science Campus, Kochi 41, Kerala, India e-mail Id-memonisha4u@gmail.com
1.31 billion in India. The contraceptive acceptance rate according to national family health survey 2011 is $56 \%$. Contraceptive acceptance needs to be increased, if population growth needs to be controlled. The extend of acceptance of contraceptive method still varies within societies, among different castes, religious group, at an individual, family and community level with their root in the socioeconomic and cultural milieu of Indian society ${ }^{1}$

It is cited in the report that globally over $10 \%$ of all women do not have any assess to or are not using any contraception. It is estimated that satisfying the unmet need for family planning alone could reduce the number of maternal death due to induced abortion. ${ }^{2}$ Family planning in India is based on efforts largely sponsored by Indian government. In the 1965-2009 
period, contraceptive usage has more than tripled (from $13 \%$ of married women in 1970 to $48 \%$ in 2009 ) and the fertility rate more than halved (from 5.7\% in 1966 to $2.4 \%$ in 2012), but the national fertility rate is high enough to cause long term population growth. India adds up to 1000000 people to its population every 20 days. $^{3}$

The ineffective use of contraceptives or failure to use contraceptives result in medical termination of pregnancies. Such as unplanned pregnancies among adult women and young girls will also end in medical termination of pregnancies. An unwanted pregnancy may lead to induced abortion. Abortion outside the medical setting (criminal abortion) is one of the most dangerous consequences of unwanted pregnancy. Such termination of pregnancies could have been prevented if contraceptives had been used consistently and appropriately. ${ }^{4}$

A study was conducted on contraceptive knowledge, practices and utilization of services in the rural areas of India among 1, 17, 465 eligible women selected from 28 districts. The study found that out of 1, 17, 465 eligible women 14, 276 were using contraceptives and 17, 082 were not using any family planning method. Among contraceptive users only $26 \%$ of women were using spacing method. Almost all women $98.8 \%$ were using a contraceptive method with the knowledge of their husband and had their support for continuing the same. The most common reason given for not using any family planning method was family not completed (34.6\%) and fear of side effects $(10.1 \%) .^{5}$

According to 2011 census, the population of India is 1210.19 million comprising 586.47 million (48.5\%) females and 623.72 million (51.5\%) males. India is one of the largest populous country in the world next to China. The higher fertility rate in India is attributed to limited use of contraceptives, low level of literacy and traditional way of life. ${ }^{6}$

Awareness of contraception is limited to married women in India. However the vast majority of married Indian women's reported significant problems in assessing a choice of contraceptive method. ${ }^{7}$ In $2009,48.3 \%$ of married women were estimated to use a contraceptive method, that is more than half of all married women did not. About three fourth of these were using female sterilization which is by far the most prevalent birth control method in India. Condoms at a mere $3 \%$ were the next prevalent method. ${ }^{8}$
According to world health organization, every year in the world there are an estimated 40-50 million abortions. This corresponds to approximately 125000 abortion daily.18 Unsafe abortions are killing a women every 2 hours in India (approximately 4000 death a year) according to estimates and calculations by sample registration system(SRS). A lancet paper on 2007 said that there were 6.4 million abortion, of which 3.6 million were unsafe. ${ }^{9}$ According to 2011 census induced abortion rate is $5,00,793$,were institution wise abortion varies from $32.0 \%-73.9 \%{ }^{10}$

In our setting the knowledge regarding the temporary contraception is poor and this result in abortion and delivery of unwanted child, in this circumstance the temporary contraceptive device like copper $\mathrm{T}$ can be encouraged. The multipara mothers are encouraged to use temporary contraceptive devices till their child reaches 5 years due to the increased susceptibility of diseases in that age group. By providing adequate information about temporary contraception, MPT's due to unplanned pregnancy can be reduced and there by MMR.

As government of India has put forward many programs for implementing family planning services to the community, majority of people are not utilizing the method properly due to the lack of knowledge, misconceptions etc. resulting in unplanned pregnancies and legal abortions. So the investigator planned to conduct a video assisted teaching program regarding temporary family planning method to postnatal mothers of Govt. T.D. Medical College Hospital Alappuzha, because audio visual aids play a very constructive role in today's society. It plays an important role in increasing of public awareness and collect the views, information and attitude towards certain issue. It is the most powerful tool of communication in emerging world and increased the awareness and presents the real stage of society. ${ }^{11}$

\section{Materials and Method}

Research approach: Quantitative Approach

Research design: Pre experimental design, one group pre testpost test design.

Variables: Dependant variable-Knowledge and attitude, Independent variable: Video-assisted teaching program

Setting: Postnatal wards and family planning OPD of Government TD Medical College Hospital Alappuzha 
Population: All the primiparous mothers in Alappuzha.

Sample Size: 50 postnatal mothers

Sampling technique: Purposive sampling technique was used for the study ${ }^{12}$.

\section{Inclusion Criteria:}

Postnatal mothers who

1. were primiparous

2. gave birth to one live child

3. were on 2 nd day after normal vaginal delivery.

4. were able to understand Malayalam

5. were willing to participate in the study.

\section{Exclusion Criteria:}

Postnatal mothers who

1. were deaf and blind

2. had psychiatric problems

\section{Description of research tool}

Tool 1: Socio personal data sheet to assess the socio personal variables: It consists of age, education, occupation, monthly family income, place of residence, source of information regarding contraception.

Tool 2: Structured questionnaire to assess the knowledge regarding temporary family planning method: The questionnaire consists of 30 questions, with five domains including awareness about temporary contraception, copper $\mathrm{T}$, condom, oral contraceptive pills and calendar method. Each question has a score of 1. The total score for this section is 30 .

Tool 3: Modified Likert scale to assess the attitude regarding temporary family planning method: Modified Likert scale consist of 20 statements with 15 positive statements and 5 negative statements.

Reliability: The reliability was checked by split half method. The reliability of knowledge questionnaire was calculated and found to be 0.89 and for modified Likert scale was found to be 0.7 which indicated an acceptable level of reliability of tool.

Findings: The present study is aimed to evaluate the effectiveness of video-assisted teaching program on knowledge and attitude regarding temporary family planning method among postnatal mothers.
- Among 50 postnatal mothers $92 \%$ had poor knowledge and $8 \%$ had average knowledge.

- Among 50 postnatal mothers 62\% had positive attitude and $38 \%$ had negative attitude regarding temporary family planning method.

- There was a significant difference in the knowledge score regarding temporary family planning method among postnatal mothers after video-assisted teaching program at $\mathrm{p}<0.001$. So it was inferred that video-assisted teaching program had a significant effect improving the level of knowledge regarding temporary family planning method among postnatal mothers

Table 1: Mean, standard deviation and $t$ value of post test knowledge scores regarding temporary family planning method among postnatal mothers. $(n=50)$

\begin{tabular}{|l|c|c|c|}
\hline Knowledge score & Mean & SD & t \\
\hline Pre test & 7.2 & 4.89 & \\
\hline & & & $20.49^{* * *}$ \\
\hline Post test & 24.50 & 2.88 & \\
\hline
\end{tabular}

*** Significant at 0.001 level

- There was a significant difference in the mean attitude score of postnatal mothers regarding temporary family planning method after videoassisted teaching program at $p<0.001$.So it was inferred that video-assisted teaching program had a significant effect on modifying the attitude from negative to positive regarding temporary family planning method among postnatal mothers.

Table 2: Mean, standard deviation and $t$ value of post test attitude scores regarding temporary family planning method among postnatal mothers $\cdot(n=50)$

\begin{tabular}{|l|c|c|c|}
\hline Attitude Score & Mean & SD & t \\
\hline Pre test & 64.20 & 10.19 & \\
\hline & & & 12.11 \\
\hline Post test & 85.12 & 10.03 & \\
\hline
\end{tabular}

${ }^{* * *}$ Significant at 0.001 level

\section{Conclusion}

The video-assisted teaching program had a significant effect in improving the knowledge and attitude regarding temporary family planning method among postnatal mothers. Since there were significant improvements, it is considered that the video- assisted 
teaching program regarding temporary family planning method could be imparted to postnatal mothers. These nursing interventions yield good improvement in knowledge and attitude of postnatal mothers without any side effects and financial burden.

Conflict of Interest: Nothing specific-can use the study findings with proper citation of authors name.

Source of Funding: Self-finance

Ethical Clearance: Research proposal was presented before the research committee of Govt Medical college Hospital, Alappuzha. The permission was obtained from the respective head of Obstetrics and Gynecology department to conduct the study. The informed consent was obtained from the subjects before data collection. Confidentiality of data collected was ensured.

\section{References}

1. India to surpass China by 2022 to become world's most populous nation. [Internet]. Available from http://indianexpress.com/article/india/india-others/ indiato-surpass-china-by-2022-to-become-worldsmost-populous-nation/

2. Maternal health. Health topics. World health organization. 2013 [Internet]. [cited 2015]. Available from; http://www.who.int/topics/ maternal-health/en.

3. Trends in maternal mortality 1990-2012. WHO, UNICEF, UNFPA and the world bank estimates. 2012. [Internet]. [cited 2015 jun 15] Available from; http:/wwwunpfa.org/webdav/site/global/ shared/documents/publications/2012/trends-inmaternal-mortality A4-1 pdf.
4. Medical termination of pregnancy.[internet].[cited 2013 mar 12]. Available fromhhp://www.rchips. org.

5. Chandhick N, Dhillon BS, Kambo I, Saxena NC. Contraceptive knowledge, practices and utilization of services in the rural areas of India (an ICMR task force study). Indian Journal of Medical Sciences. 2003 Jul 1;57(7):303-10. Available from http:// www.bioline.org.br/request? ms03005

6. Contraception today [Internet]. Available from http://www.ncbi. nlm.nih. gov/pubmed/10894258

7. Park K. Textbook of preventive and social medicine. 23th ed. Jabalpur: M/S. Banarsidas Bhanot Publishers. 2015.

8. Usha R. Contraceptive Use among Young Married Women in India [Internet].[cited 2015 mar 14]. Available from http://fpconference. org/2009/media/DIR_169701/15f1ae857ca97193 ffff82bdffffd524. Pdf

9. Family planning; find expert advice. [Internet] [cited on 2015 mar 13]. Available from http://www.quikr. com/All/y0?imageAds $=Y$ \& utmsource $=$ yahoo \& utm_ medium $=$ cpc \& utm_term $=$ family + planning $\&$ utm_content.

10. Unsafe abortion killing a women every two hours. [Internet]. Available fromhttp://www.thehindu. com/news/national/unsafe-abortions-killing-awoman-everytwo-hours/article4686897.ece

11. Birth spacing today's perspectives [Internet] .[cited on 2015 mar 12]. Available from a http://www. unicef.org/lifeskills/files/9thStandard-Grade.pdf

12. Mathew RM, Anju Philip T, Sreejamol MG. Perceived postpartum stress and coping strategies among postnatal mothers at aims, Kochi. Asian J Pharm Clin Res 2017; 10(12):116-119 